\title{
The influence of environmental factors on the structure of caddisfly (Trichoptera) assemblage in the Nišava River (Central Balkan Peninsula)
}

\author{
A. Savić(1),, V. Ranđelović(1) M. Đorđević((2), B. Karadžić( ${ }^{(3)}$, M. Đokić( ${ }^{(4)}$, \\ J. Krpo-Ćetković( ${ }^{(5)}$
}

Received December 24, 2012

Revised March 23, 2013

Accepted April 15, 2013

\begin{abstract}
Key-words: caddisfly, river, community structure, environmental factors, river continuum concept

Monthly samples of caddisfly (Trichoptera) larvae were taken from ten localities along a $151 \mathrm{~km}$ long section of the Nišava River (eastern Serbia) during a one year study, with the aim to assessing the spatial composition of the caddisfly assemblage along the river gradient, to identify key environmental factors influencing its variability, to find out if caddisflies are suitable as biological indicators of water quality in this region, and to asses if the caddisfly assemblage in the river follows the river continuum concept. Twenty-three morphologically distinct taxa belonging to 14 genera were identified. The dominant family was Hydropsychidae with $70.34 \%$ of specimens examined, followed by Brachycentridae with $9.74 \%$ specimens. The longitudinal variability of the caddisfly assemblage has shown a clear dependence on physical and chemical parameters. The $\mathrm{CCA}$ analysis suggests that $\mathrm{BOD}_{5}$ and concentration of total phosphorus are the most important factors in structuring the caddisfly assemblage. The species diversity was greatest at localities with the highest oxygen concentration and low nutrient levels. The caddisfly assemblage proved to be useful in identifying differences in environmental conditions in the Central Balkan region.
\end{abstract}

\section{ABSTRACT}

\section{RÉSUMÉ}

L'influence des facteurs environnementaux sur la structure des communautés de phryganes (trichoptères) dans la rivière Nišava (péninsule centrale des Balkans)

Mots-clés : phryganes, rivière,
Des échantillons mensuels de larves de phryganes (trichoptères) ont été prélevés dans dix localités réparties dans un secteur long de $151 \mathrm{~km}$ de la rivière Nišava (Serbie orientale) au cours d'une étude d'un an, dans le but; d'évaluer la composition spatiale de l'assemblage de phryganes le long de la rivière, d'identifier les principaux facteurs environnementaux qui influent sur sa variabilité, pour

(1) Department of Biology and Ecology, Faculty of Sciences and Mathematics, University of Niš, Višegradska 33, Niš, Serbia

(2) Department of Mathematics, Faculty of Sciences and Mathematics, University of Niš, Višegradska 33, Niš, Serbia

(3) Institute for Biological Research "Siniša Stankovic”", University of Belgrade, Bulevar Despota Stefana 142, Belgrade, Serbia

(4) Department of Geography, Faculty of Sciences and Mathematics, University of Niš, Višegradska 33, Niš, Serbia

(5) Faculty of Biology, University of Belgrade, Studentski trg 16, Belgrade, Serbia

* Corresponding author: anka@pmf.ni.ac.rs 
structure de communauté, facteurs environnementaux, concept de continuum fluvial savoir si les trichoptères sont appropriés comme indicateurs biologiques de la qualité de l'eau dans cette région, et d'évaluer si l'assemblage de phryganes dans la rivière suit le concept de continuum fluvial. Vingt-trois taxons morphologique, ment distincts appartenant à 14 genres ont été identifiés. La famille dominante était les Hydropsychidae avec 70,34 \% des spécimens examinés, suivis par les Brachycentridae avec $9,74 \%$ des spécimens examinés. La variabilité longitudinale de l'assemblage de phryganes a montré une dépendance claire des paramètres physiques et chimiques. L'analyse CCA suggère que la $\mathrm{DBO}_{5}$ et la concentration de phosphore total sont les facteurs les plus importants dans la structuration de l'assemblage de phryganes. La diversité des espèces était la plus élevée dans des localités ayant la plus forte concentration d'oxygène et de faibles niveaux d'éléments nutritifs. L'assemblage de phryganes s'est avéré utile pour identifier les différences dans les conditions de l'environnement dans la région centrale des Balkans.

\section{INTRODUCTION}

Caddisflies (Trichoptera) are one of the most diverse orders among aquatic insects. They are widely distributed in different types of habitats, occupying a wide range of trophic levels (Cummins, 1973; Wiggins and Mackay, 1978; Mackay, 1984). The high diversity and ecological success of these insects are the result of their ability to build portable cases, nets, and shelters from mineral or organic particles using silk secretion (Mackay and Wiggins, 1979). Trichoptera larvae are important components of aquatic trophic webs (Resh and Rosenberg, 1984). The caddisfly larvae are among the best indicator groups of macroinvertebrates for assessing water quality, as they have limited mobility and a relatively long life span; different species vary in sensitivity to various types of pollution and are easily sampled (Dohet, 2002). Temporal and spatial distribution patterns of lotic larval caddisfly assemblages in relation with environmental variables have been investigated extensively in the past (Huryn and Wallace, 1988; Schmera, 2004; Hughes, 2006; Galbraith et al., 2008). Among the environmental variables that have a strong impact on the distributional pattern of aquatic organisms are the geomorphology of the stream bed (Reid et al., 2010; Skuja and Spungis, 2010), land-use (Hughes, 2006; Helms et al., 2009), substrate type (Buss et al., 2004; Urbanič et al., 2005), hydraulic conditions (Statzner and Dolédec, 2011), and water temperature (Townsend et al., 1997; Hughes, 2006; Fengqing et al., 2012).

Macroinvertebrate communities in streams are also greatly influenced by changes in the source of energy input of allochthonous (fallen tree leaves) or autochthonous (algal production) material in streams (McTammany, 2004). Shifts in food sources can directly or indirectly change the quality and quantity of available food resources for macroinvertebrates (Culp, 1987). The source of energy in streams changes seasonally, with loss of natural riparian cover, and as a result of anthropogenic inputs of inorganic and organic compounds (Sponseller and Benfield, 2001; Paul et al., 2006; Dolédec and Statzner, 2010; Tank et al., 2010).

In temperate climates, ecologically relevant factors (flood disturbance frequency, bottom substrate type, discharge, temperature, light, salinity, etc.) change considerably and in a rather predictable way from headwaters to river mouths (Hynes, 1970; Gordon et al., 1992; Allan, 1995; Statzner and Dolédec 2011). The river continuum concept (RCC) (Vannote et al., 1980) emphasizes the impact of geomorphological factors on the biological community in a stream. The concept states that the community in a natural stream system is structured in such a way as to maximize the efficiency of energy utilization through orderly processing of organic matter from headwater streams to large rivers. In this study, we wanted to examine whether the caddisfly assemblage matches the RCC in the river, or if its trophic structure (distribution pattern of functional feeding groups) is more influenced by pollution.

The Nišava River was chosen for this research because there are several large settlements, with highly developed industry, distributed along its entire course, causing pollution 


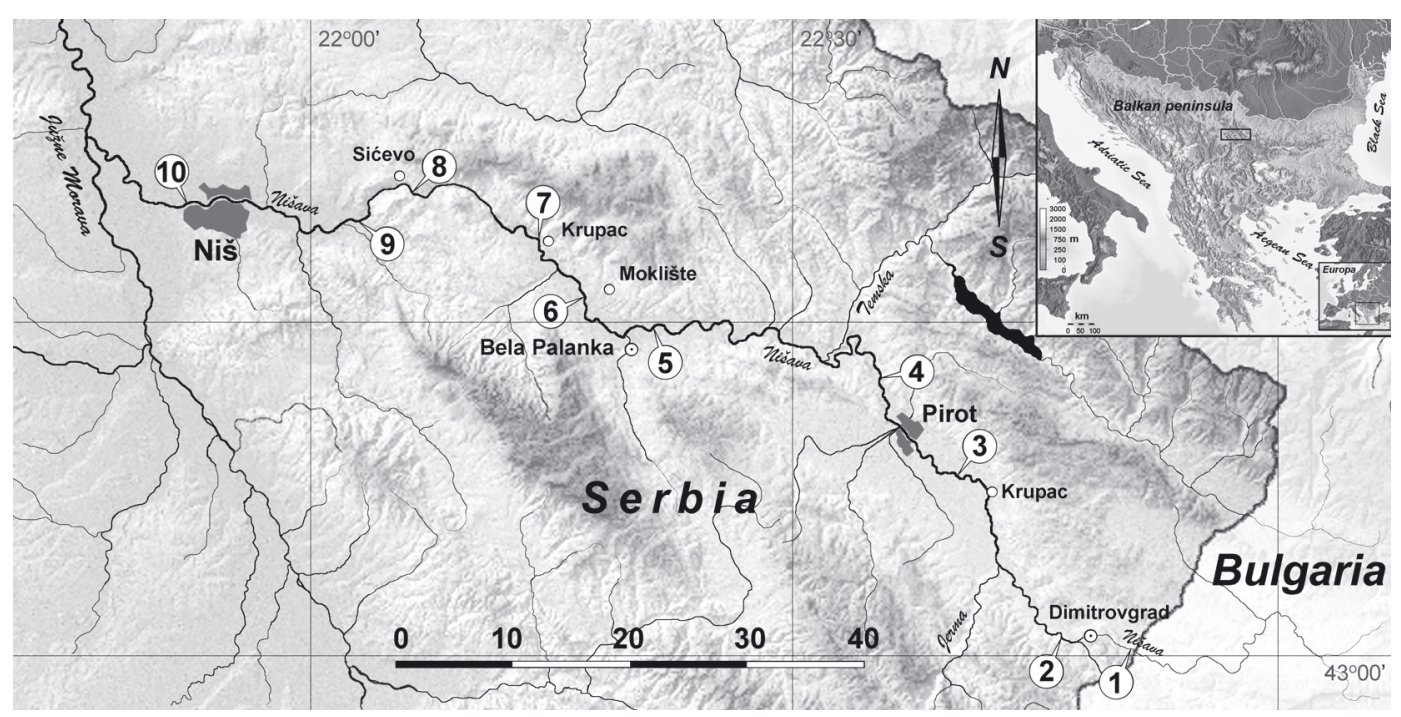

Figure 1

The map of the studied area with localities.

immediately downstream of communal and/or wastewater disposal sites. However, the distance between these settlements is long enough to allow for self-purification processes to be activated and zones of recovery to develop. Furthermore, it was possible to study almost the entire river course, except the uppermost section in Bulgaria, including the more natural areas and those without human impacts. Since it is expected that changes in the caddisfly assemblage would correlate with changes in the physical and chemical characteristics of the water, we tried to assess the significance of the relatedness to specific factors, particularly those that indicate the ecosystem's trophic or pollution status.

The previous studies of the macrozoobenthos of the Nišava River are rather scarce. They include two saprobiological studies (Jakovčev, 1985; Branković et al., 2007), a study on seasonal dynamics of macrozoobenthos in two tributaries of the river (Živić et al., 2005), and two studies on ecology of the mayflies (Savić et al., 2010, 2011). There are no previous data on structure of caddisfly assemblage in the river.

The aims of this study were: (1) to assess the spatial composition of the caddisfly assemblage along the river gradient; (2) identify key environmental factors influencing its variability; (3) determine if caddisflies are suitable as biological indicators of water quality in this region;

(4) and to assess if the caddisfly assemblage in the river is consistent with the RCC.

\section{MATERIALS AND METHODS}

\section{> STUDY SITE AND SAMIPLING PROCEDURES}

The Nišava River (Figure 1) belongs to the Black Sea drainage basin. It originates in western Bulgaria, on the Stara Planina Mt., and flows in a southeast-northwest direction. It is $218 \mathrm{~km}$ long, of which $67 \mathrm{~km}$ flows through Bulgaria, and $151 \mathrm{~km}$ through Serbia. It is the longest tributary of the Južna Morava River and also is the largest one in terms of discharge $\left(36 \mathrm{~m}^{3} \cdot \mathrm{s}^{-1}\right)$. The river is a 4th to 7 th order stream (according to Strahler, 1952). Ten localities were chosen along the entire course of the Nišava River in Serbia. The odd numbered localities are positioned upstream of the settlements, and even numbered downstream of the settlements. Sampling was performed each month, from May 2006 to April 2007. All localities were sampled on a single day during each field trip.

Seventeen environmental variables, grouped into four subsets - spatial $\{S\}$, chemical $\{C\}$, physical $\{P\}$, and biotic $\{B\}-$ were measured at each locality during each field trip. The subset 
$\{S\}$ includes the distance of each sampling point from the river mouth of the Nišava River (DM) and the upstream/downstream position of each sampling point from the nearest wastewater discharge point (PW). Binary code was used to indicate whether the sampling point is located upstream (0) or downstream (1) of the nearest wastewater discharge point.

The subset $\{C\}$ includes biochemical oxygen demand $\left(\mathrm{BOD}_{5}\right)$, $\mathrm{pH}$, and concentrations of oxygen, nitrogen, and phosphorus. Biochemical oxygen demand $\left(\mathrm{BOD}_{5}\right)$ was estimated using the standard methodology recommended by APHA (1999). Dissolved oxygen and pH were measured using a WTW ${ }^{\circledR}$ Multi 340i probe. The concentration of total nitrogen $(N)$ and phosphorus $(\mathrm{P})$ were determined in the field, using a Photometer-System PC MultiDirect Lovibond ${ }^{\circledR}$ meter. The subset $\{\mathrm{P}\}$ includes river depth, river width, watershed area, substrate type, temperature, conductivity, turbidity, water velocity, and water residence time. River depth was estimated using a rigid meter rule with an accuracy of $\pm 1 \mathrm{~cm}$. The watershed area was calculated using the ArcGIS software (ESRI, 2009). Scanned topographic maps at 1:25000 scale were added in ArcMAP and then georeferenced; the polygons that correspond to sub-areas were constructed using the contour lines with ArcMAP Calculate Geometry Tool. The percentage of substrate was observed visually; the classification of mineral substrates by particle sizes according to Wentworth (1922) and Verdonschot (1999) was used. Since larger substrates require greater stream power for movement, they are physically more stable (Gurtz et al., 1984); thus, pebbles, cobbles and boulders consolidated a stable substrate. Temperature and conductivity were measured using a WTW ${ }^{\circledR}$ Multi 340i probe. Water turbidity was measured with a Lovibond ${ }^{\circledR}$ Checkit device. The flow velocity was calculated using a mechanical current meter (Seba Universal Current Flow Meter F1). Water residence time was calculated with the formula

$$
R=0.08 A_{d}^{0.6} / Q^{0.1}
$$

where $R$ is water residence time at the sampling site (d), $A_{d}$ is watershed area upstream of the sampling site $\left(\mathrm{km}^{2}\right)$, and $Q$ is river discharge $\left(\mathrm{m}^{3} \cdot \mathrm{s}^{-1}\right)$ (Soballe and Kimmel, 1987).

The subset $\{B\}$ includes the periphyton mass and the percentage of canopy shadow. Periphyton was sampled by gentle scraping with a brush (up to $10 \mathrm{~cm}^{2}$ of surface), three times at the left bank, three times in the middle of the river, and three times at the right bank along a transect, in order to include various water depths. In general, the stone was removed from the stream before scraping so that scraped algae were not washed away (Lowe and Laliberte, 2007). The periphyton collected in this way was combined into a single sample, and its wet weight was measured. The percentage of canopy shadow was estimated by visual observation.

Macrozoobenthos were sampled at each locality over a $50 \mathrm{~m}$ river stretch with a square frame kick net $(35 \times 35 \mathrm{~cm}$, mesh size $300 \mu \mathrm{m})$. Three 3-minute samples were taken during each visit to include different substrates (boulder, cobble, pebble, sand, silt, and detritus) and flow regime zones at each location. The net was held perpendicular to the flow and the substrate was vigorously disturbed in front of the net. As the substrate was disturbed, sampling moved progressively upstream. The three samples were then pooled, representing a single monthly sample for each site. This sampling procedure was previously evaluated by preliminary test sampling, and three replicates proved to be sufficient to capture the maximum number of taxa. All samples were elutriated in the field and the organisms were fixed in $4 \%$ formaldehyde solution and returned to the laboratory for sorting. The material was identified using identification keys for Trichoptera (Wallace et al., 1990; Edington and Hildrew, 1995; Waringer and Graf, 1997, 2011; Lechthaler and Stockinger, 2005).

To examine if the caddisfly assemblage is consistent with the RCC, which describes longitudinal patterns in allochthonous and autochthonous energy input and associated feeding categories of macroinvertebrates along the lotic continuum (Cummins, 1973; Vannote et al., 1980 ), it was necessary to determine the functional feeding groups. This was done according to Graf et al. $(2006,2008,2011)$. 


\section{> DATA ANALYSIS}

Multivariate analyses permit a considerable level of understanding of community structure and its relationships with corresponding environmental properties (Ormerod and Edwards, 1987). We applied a correspondence analysis (CA) and a cluster analysis in order to detect patterns of variation in the caddisfly assemblage structure. Community ecologists have repeatedly confirmed that, compared to "linear ordination methods" (principal components analysis, principal coordinate analysis, and their canonical variants), CA is a more appropriate method, especially in the case of species turnover along spatial or environmental gradients (ter Braak and Prentice, 1988; Legendre and Gallagher, 2001). Since CA is extremely sensitive to rare species and species-poor samples, we performed downweighting of rare categories (Hill 1979; McCune \& Mefford 1999). For agglomerative classification, we used the UPGMA method (Sokal and Rohlf, 1995) in combination with the chi-square distance.

The canonical correspondence analysis (CCA) (ter Braak 1986) was applied to test the influence of environmental variables on the caddisfly assemblage. Environmental variables may be highly correlated or "redundant" with one another. In such cases the CCA is sensitive to overfitting the problem (McCune, 1997). This could lead to arbitrary inflation of the variance explained due to randomly covarying factors that are not ecologically related to the assemblage structure. To avoid the overfitting problem, we performed a forward selection of environmental variables (ter Braak, 1986; Blanchet et al., 2008; Legendre et al., 2011). At each regression step, the variable that adds most to the explained variance in data is selected. The statistical significance of the null hypothesis that the selected variables are unrelated to caddisfly assemblage was tested by means of unrestricted Monte Carlo permutation tests (ter Braak and Wiertz, 1994).

The influence of four subsets of environmental variables on the caddisfly assemblage was analyzed using a partial CCA. This method was applied in order to detect fractions of the total assemblage variability explained by a subset of explanatory variables, when subsets of other variables are held constant. Such variation partitioning procedure is a multivariate equivalent of the partial regression (Borcard et al., 1992). All classification and ordination methods were done using the FLORA software package (Karadžić et al., 1998; Karadžić and Marinković, 2009). Shannon's ( $H^{\prime}$ ) and Margalef's (d) diversity indices were also calculated, as well as Simpson's dominance index (D) (Krebs, 2001).

A repeated measures analysis of variance (ANOVA) and multiple range tests (Fisher's least significant difference (LSD) procedure) were applied using $\mathrm{R}$ software to determine the significance of differences in the total phosphorus, total nitrogen, oxygen, and the number of species between localities.

\section{RESULTS}

The analyses of environmental parameters showed that locality 3 stands out from the other localities for the lowest cumulative average annual concentration of total phosphorus and total nitrogen (TP + TN). Nitrogen concentration is lowest at this locality, and phosphorus concentration is lower only at locality 1 . (Table I). Oxygen content, which has been used as one of the most important indicators of the ecosystem health for a long time (Cox, 2003), is highest at locality 7 . Locality 4 has the highest cumulative average annual TP + TN concentration, highest total $N$ and very high values of $\mathrm{BOD}_{5}$. Locality 10 , with the highest average periphyton mass, lowest turbidity and lowest oxygen (Table I). One of the shared features of localities 4 and 10 is a somewhat higher percentage of agricultural areas (which is also the case with the localities 1 and 2) (Table II). The ANOVA showed that there was a significant difference between localities in regard to the total phosphorus $(F=7.6, p=0.0001, d f=9)$, total nitrogen $(F=5.6, p=0.001, d f=9)$, and oxygen concentration $(F=7.00, p=0.0001, d f=9)$. The post-hoc test showed that locality 10 significantly differs from other localities regarding both the total phosphorus (except from locality 4) and the oxygen concentration, and that locality 4 is significantly differs from other localities regarding the nitrogen concentration. 
Table I

The average annual values of environmental parameters at each locality studied along the Nišava River.

\begin{tabular}{|c|c|c|c|c|c|c|c|c|c|c|c|}
\hline & & \multicolumn{10}{|c|}{ Localities } \\
\hline Parameter & Abbrev. & 1 & 2 & 3 & 4 & 5 & 6 & 7 & 8 & 9 & 10 \\
\hline $\begin{array}{l}\text { Conductivity, } \\
\text { in } \mathrm{S} \cdot \mathrm{cm}^{-1}\end{array}$ & Con & 496.00 & 536.42 & 460.08 & 459.42 & 395.75 & 403.83 & 414.17 & 411.08 & 413.58 & 575.67 \\
\hline \begin{tabular}{|l|} 
Total nitrogen, \\
in $\mathrm{mg} \cdot \mathrm{L}^{-1}$
\end{tabular} & $\mathrm{TN}$ & 0.27 & 0.28 & 0.08 & 0.34 & 0.10 & 0.12 & 0.12 & 0.08 & 0.09 & 0.21 \\
\hline Oxygen, in $\mathrm{mg} \cdot \mathrm{L}^{-1}$ & $\mathrm{O}_{2}$ & 6.72 & 7.28 & 8.04 & 7.09 & 7.85 & 8.34 & 8.37 & 7.98 & 7.56 & 6.50 \\
\hline $\mathrm{BOD}_{5}$, in $\mathrm{mg} \cdot \mathrm{L}^{-1}$ & $\mathrm{BOD}_{5}$ & 1.68 & 3.04 & 2.74 & 4.16 & 3.08 & 3.37 & 3.61 & 3.08 & 3.17 & 2.99 \\
\hline Depth, in cm & $\mathrm{D}$ & 57.50 & 68.33 & 89.58 & 144.17 & 145.00 & 162.92 & 142.50 & 60.83 & 166.67 & 96.67 \\
\hline \begin{tabular}{|l|} 
Total phosphorus, \\
in $\mathrm{mg} \cdot \mathrm{L}^{-1}$
\end{tabular} & TP & 0.02 & 0.08 & 0.04 & 0.10 & 0.07 & 0.07 & 0.07 & 0.06 & 0.07 & 0.11 \\
\hline \begin{tabular}{|l|} 
Total nitrogen + \\
total phosphorus, \\
in $\mathrm{mg} \cdot \mathrm{L}^{-1}$
\end{tabular} & $\mathrm{TN}+\mathrm{TP}$ & 0.29 & 0.36 & 0.12 & 0.44 & 0.17 & 0.19 & 0.19 & 0.14 & 0.16 & 0.32 \\
\hline pH & $\mathrm{pH}$ & 7.56 & 6.54 & 6.17 & 6.59 & 6.98 & 6.56 & 6.30 & 7.34 & 6.15 & 6.54 \\
\hline Shadow, in \% & Shad & 28.33 & 10.42 & 8.75 & 26.67 & 10.00 & 30.42 & 27.92 & 21.25 & 51.67 & 7.92 \\
\hline Width, in m & Wdt & 8.67 & 11.38 & 20.75 & 22.25 & 39.25 & 40.42 & 31.67 & 39.25 & 39.50 & 56.50 \\
\hline $\begin{array}{l}\text { Temperature, } \\
\text { in }{ }^{\circ} \mathrm{C}\end{array}$ & $\mathrm{T}$ & 11.38 & 11.93 & 13.53 & 12.58 & 12.85 & 13.58 & 13.89 & 13.49 & 13.56 & 15.53 \\
\hline $\begin{array}{l}\text { Water velocity, } \\
\text { in } \mathrm{m} \cdot \mathrm{s}^{-1}\end{array}$ & Wv & 0.95 & 0.87 & 0.64 & 0.65 & 0.80 & 0.65 & 0.83 & 0.83 & 1.04 & 1.00 \\
\hline Turbidity, in NTU & $\mathrm{Tu}$ & 26.60 & 35.92 & 12.33 & 18.20 & 21.98 & 20.72 & 5.28 & 12.90 & 6.94 & 3.75 \\
\hline $\begin{array}{l}\text { Water residence } \\
\text { Time, in d }\end{array}$ & WRT & 2.86 & 3.68 & 5.57 & 6.07 & 7.57 & 7.81 & 7.98 & 8.11 & 8.19 & 8.69 \\
\hline $\begin{array}{l}\text { Stable substrate, } \\
\text { in } \%\end{array}$ & SS & 67.50 & 79.67 & 78.33 & 46.50 & 76.67 & 52.58 & 83.75 & 89.17 & 66.67 & 70.42 \\
\hline $\begin{array}{l}\text { Mass of } \\
\text { periphyton, } \\
\mathrm{g} \cdot \mathrm{dm}^{-2}\end{array}$ & Mper & 7.57 & 10.74 & 7.45 & 8.13 & 7.72 & 5.86 & 7.23 & 7.01 & 7.89 & 13.31 \\
\hline
\end{tabular}

Caddisfly larvae collected at the studied sites belong to 23 species within 9 families (Table III). The family with the greatest number of species was Hydropsychidae, represented by ten species from three genera (43.48\% of all species), followed by Beraeidae (three species from two genera), Rhyacophilidae (three species in a single genus), and Sericostomatidae (two species in two genera). The remaining five families (Brachycentridae, Ecnomidae, Goeridae, Limnephilidae and Phryganeidae) were represented by a single species each.

Considering the number of collected specimens, $70.34 \%$ were hydropsychids, $9.74 \%$ brachycentrids, $5.51 \%$ rhyacophilids, $3.80 \%$ ecnomids, and $2.97 \%$ were a combination of sericostomatids, goerids, and limnephilids. The families with the smallest number of collected specimens were beraeids (1.27\%) and phryganeids $(0.42 \%)$.

The lowest species richness occurred at localities 4 and 10 (one species), while the greatest richness occurred at localities 7 (16 species) and 3 (12 species). The following species were found at only one locality each - Ernodes articularis (Pictet, 1834) at locality 1, Beraea pullata (Curtis, 1834) at locality 3, Trichostegia minor (Curtis, 1834) at locality 5, and Beraeodes minutus (Linnaeus, 1761), Sericostoma personatum (Kirby \& Spence, 1826), Rhyacophila fasciata Hagen, 1859, and Rhyacophila munda McLachlan, 1862, at locality 7, while the species Hydropsyche contubernalis McLachlan (1865) was present at seven of ten studied localities (Table III). The ANOVA showed that there was a significant difference between localities regarding the species richness $(F=4.6, p=0.002, d f=9)$, and the post-hoc test showed that locality 7 (the locality with the highest number of species) is significantly different from 


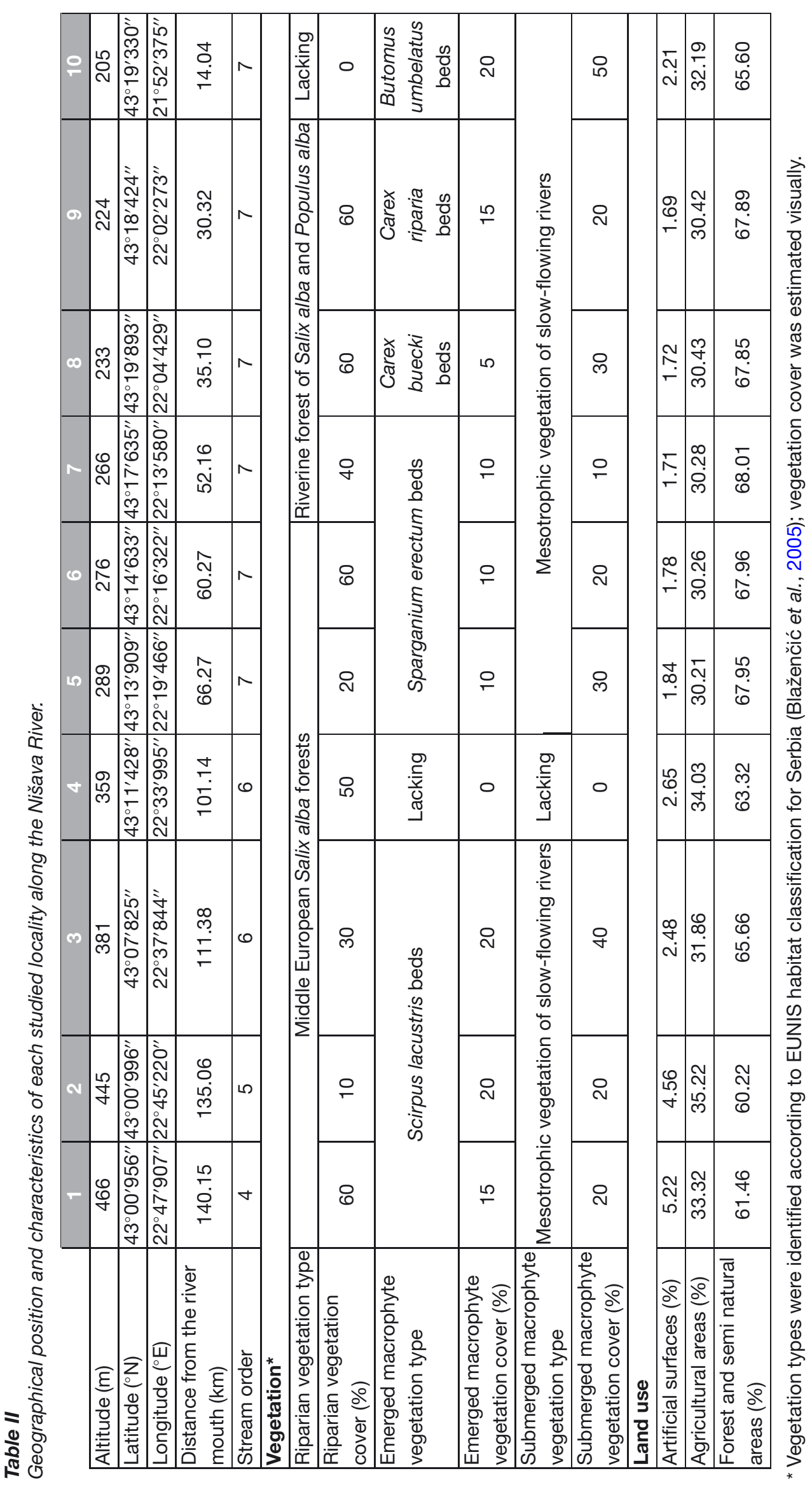


Table III

The occurrence of caddisfly (Trichoptera) species at each locality studied along the Nišava River (ind $m^{-2}$ ).

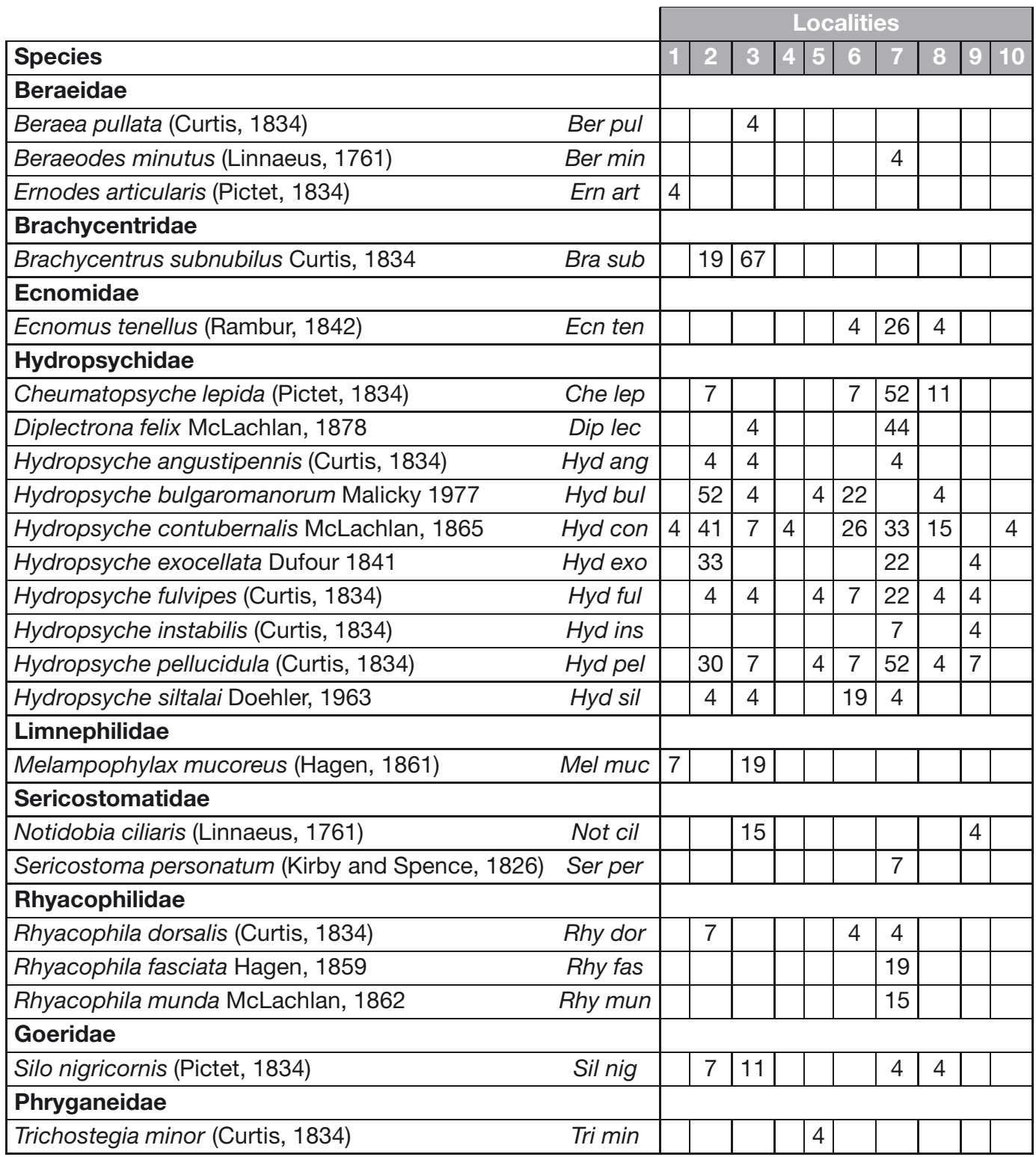

all other localities, while localities 4 and 10 are the least different between each other in this aspect $(p=1)$.

Since the results suggest that localities 4 and 10 are polluted localities, we labeled them as the group A and all other localities as the group B, and reran the ANOVA based on these two classes of data. Oxygen concentration and species richness were found to be higher in Group B $(F=10.9, p=0.003, d f=1$, and $F=5.7, p=0.024$, $d f=1$, respectively), and both total phosphorus and total nitrogen were found to be significantly higher in Group $A(F=21.5$, $p=0.0001$, $d f=1$, and $F=8.1, p=0.008, d f=1$, respectively) (Figure 2).

The highest annual species diversity, expressed using Shannon's and Margalef's diversity indices, was recorded at locality 7 (the locality with the highest oxygen concentration) (Table IV); accordingly, the Simpson's dominance index was the lowest at this locality. The lowest annual average diversity was found at localities 4 and 10, where low oxygen concentration, high $\mathrm{TP}+\mathrm{TN}$, and high $\mathrm{BOD}_{5}$ were recorded. 

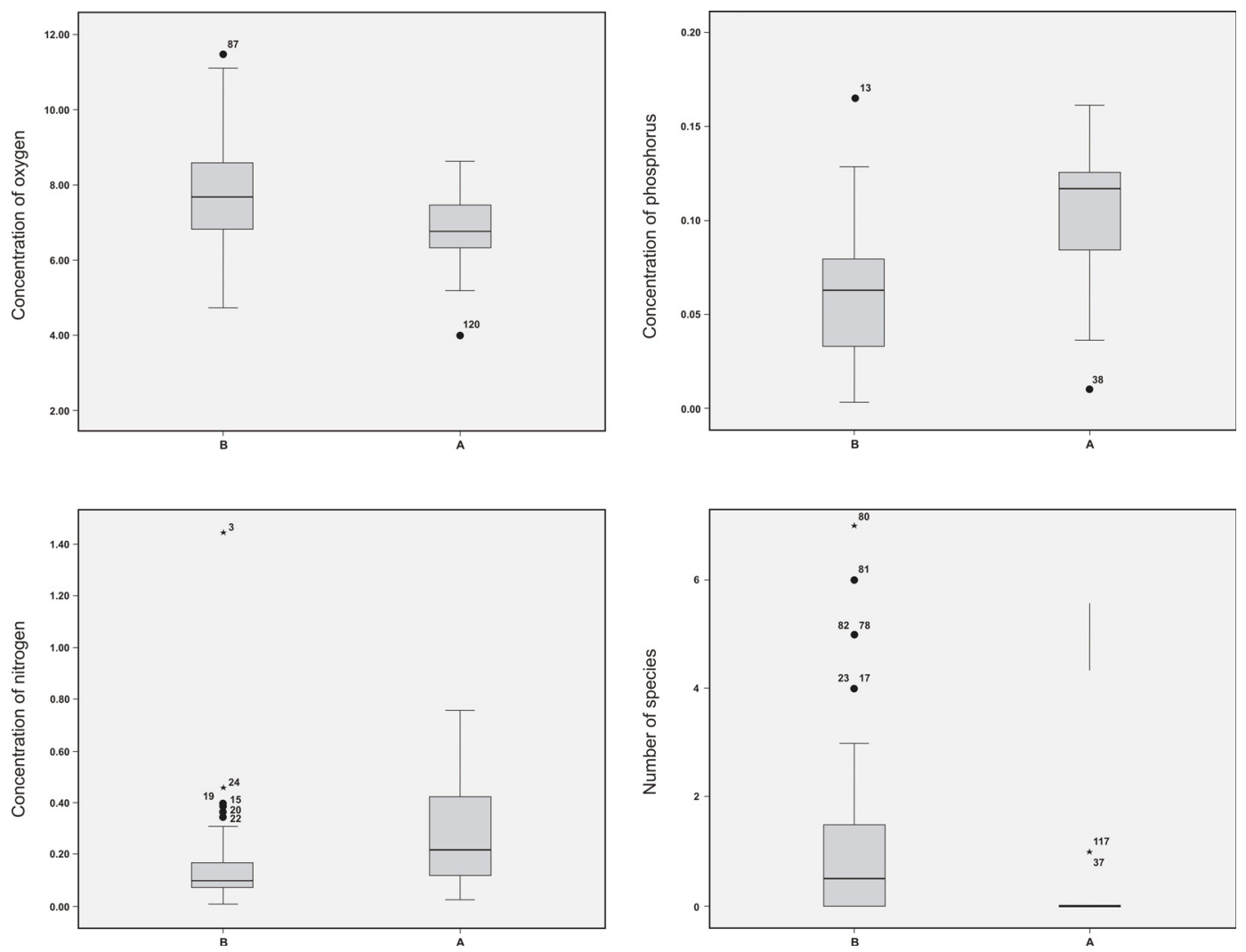

Figure 2

Box-and-Whisker plot: (a) concentration of oxygen; (b) concentration of total phosphorus; (c) concentration of total nitrogen; (d) number of species. Group A: localities 4 and 10; Group B: all other localities.

\section{Table IV}

The average annual values of Shannon's diversity index ( $\left.H^{\prime}\right)$, Simpson's dominance index (D) and Margalef's diversity index (d).

\begin{tabular}{|l|c|c|c|c|c|c|c|c|c|c|}
\cline { 2 - 10 } \multicolumn{1}{c|}{} & \multicolumn{8}{c|}{ Localities } \\
\hline Diversity indices & 1 & 2 & 3 & 4 & 5 & 6 & 7 & 8 & 9 & 10 \\
\hline Shannon's diversity index (H') & 1.04 & 2.03 & 1.89 & 0.00 & 1.39 & 1.84 & 2.42 & 1.75 & 1.55 & 0.00 \\
\hline Simpson's index & 0.37 & 0.16 & 0.24 & 1.00 & 0.25 & 0.18 & 0.11 & 0.21 & 0.22 & 1.00 \\
\hline Margalef's index & 1.43 & 2.48 & 2.97 & 0.00 & 2.17 & 2.15 & 3.37 & 2.41 & 2.22 & 0.00 \\
\hline
\end{tabular}

All four FFG of caddisflies were observed only at locality 3 and three FFG at localities 1 and 7 , which suggest that these are the localities with a more complete trophic structure in comparison with other localities (Table V).

\section{DISCUSSION}

Among the hydropsychids, which were represented by the greatest number of species, $\mathrm{Hy}$ dropsyche angustipennis (Curtis 1834) was found only at localities with good water quality (3 and 7), as defined by Savić (2012), while H. contubernalis was found at both polluted (4) and clean localities ( 3 and 7). These two species differ from each other in their basic tolerance of organic enrichment. Such an ecological difference is supported by their significant phylogenetic difference (Statzner and Dolédec, 2011). Furthermore, Graf et al. (1995) state that $H$. bulgaromanorum is less resistant to water pollution than $H$. contubernalis, while Czachorowski and Serafin (2004) state the opposite - that $H$. bulgaromanorum is tolerant to 


\section{Table V}

Annual percentage of FFGs at each sampling locality along the Nišava River.

\begin{tabular}{|l|c|c|c|c|c|c|c|c|c|c|}
\cline { 2 - 12 } \multicolumn{1}{c|}{} & \multicolumn{10}{c|}{ Localities } \\
\hline FFG & 1 & 2 & 3 & 4 & 5 & 6 & 7 & 8 & 9 & 10 \\
\hline Predators & 25.0 & 7.1 & 7.5 & 0.0 & 0.0 & 3.9 & 20.9 & 16.7 & 0.0 & 0.0 \\
\hline Collectors & 25.0 & 92.9 & 70.0 & 100 & 75.0 & 96.2 & 76.6 & 83.3 & 83.3 & 100 \\
\hline Shreders & 50.0 & 0.0 & 12.5 & 0.0 & 25.0 & 0.0 & 0.0 & 0.0 & 0.0 & 0.0 \\
\hline Scrapers & 0.0 & 0.0 & 10.0 & 0.0 & 0.0 & 0.0 & 2.3 & 0.0 & 16.7 & 0.0 \\
\hline
\end{tabular}

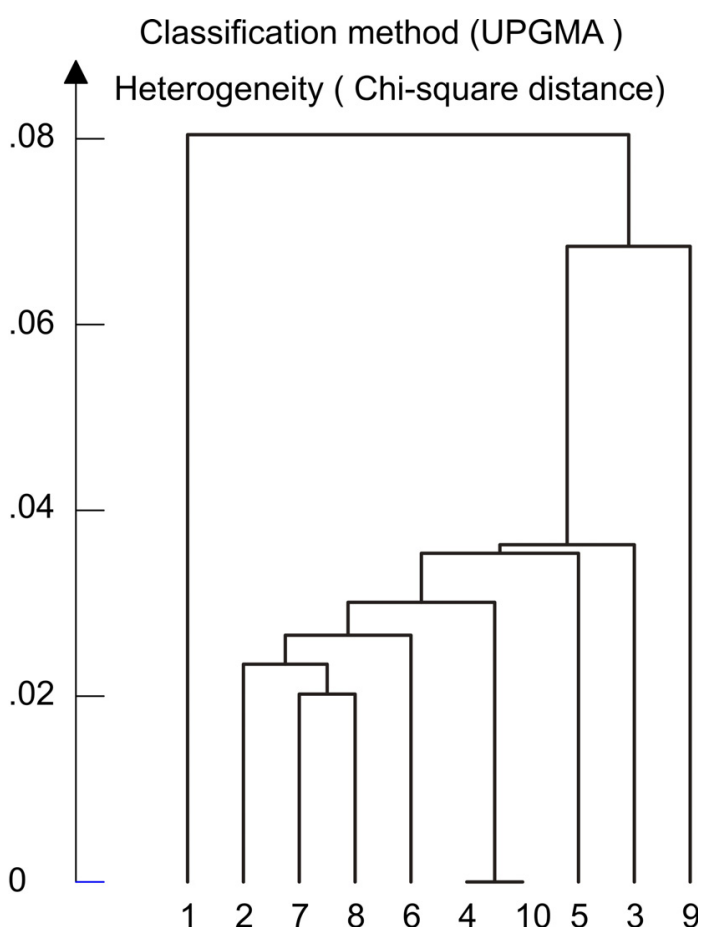

Figure 3

Cluster analysis of the caddisfly assemblage in the Nišava River.

water pollution, and $H$. contubernalis is less resistant, assuming that the tolerance to water pollution of the genus Hydropsyche is not very clear and ambiguous. This suggests that it is not justified to use only the genera of Trichoptera as biological indicators.

At the family level, Brachycentridae and Sericostomatidae are the most susceptible to pollution of all Trichoptera families (Bonada et al., 2004), and in the present study they were recorded only at the least polluted localities (3 and 7). The factors limiting the distribution of Hydropsychidae change with the changing constitution of the water and it is often not simple to distinguish between habitat quality or water quality as primary causes (Stuijfzand et al., 1999), which implicates that this family is not suitable as a biological indicator.

Localities 2, 4, 6, and 10 are positioned downstream of wastewater discharge sites of the cities Dimitrovgrad, Pirot, Bela Palanka, and Niš, and locality 8 downstream of a group of small settlements. Anthropogenic influence is evident at these sites, particularly at localities 4 and 10, which are characterized with the lowest species richness, lowest average annual oxygen concentration, and highest annual nutrient (nitrogen and phosphorus) concentration. Only one caddisfly species (Hydropsyche contubernalis) was recorded at these localities. The cluster analysis (Figure 3) also emphasizes the specific features of localities 4 and 10. On the other hand, locality 7 is the locality with the highest species richness (16 species). Species Beraeodes minutus, Sericostoma personatum, Rhyacophila munda, and $R$. fasciata were found only at this locality. 


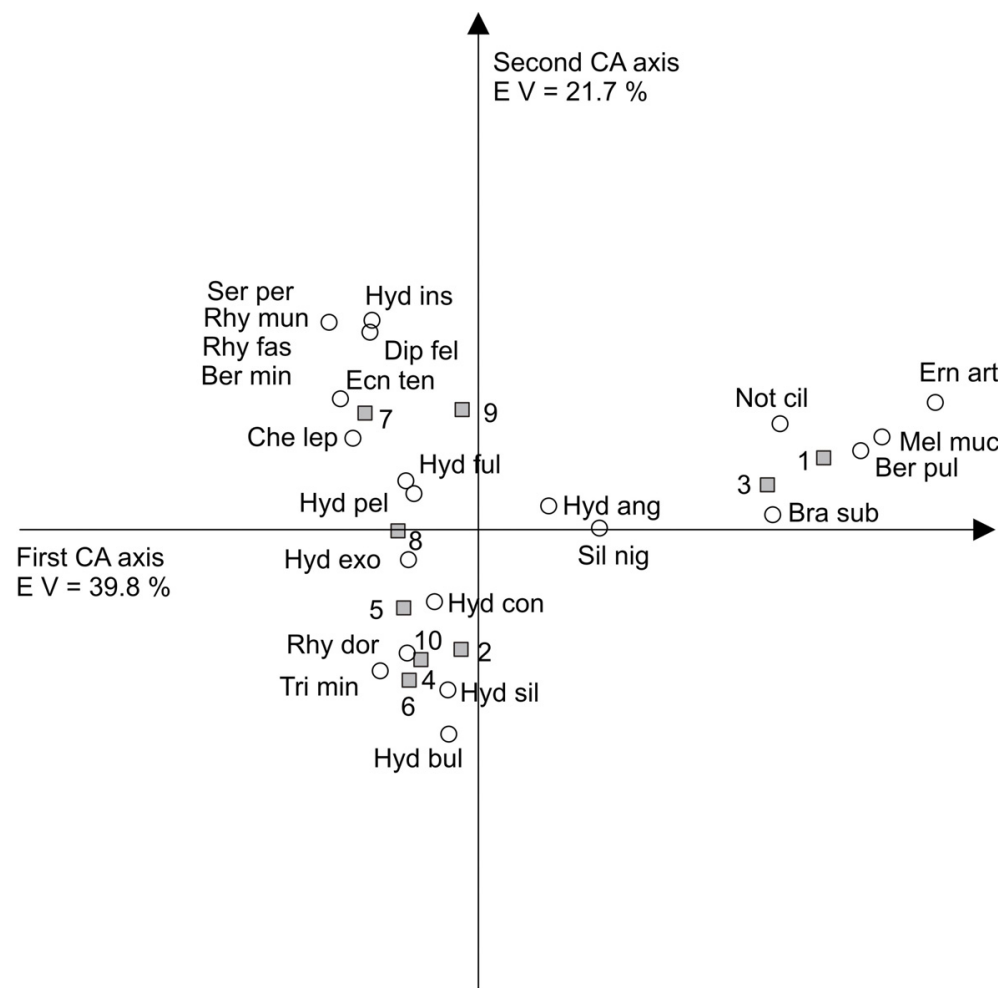

\section{Figure 4}

Correspondence analysis of the caddisfly assemblage in the Nišava River; first two axes explain 61.5\% of total data variability.

The index of trophic completeness (ITC) sensu Pavluk et al. (2000) at locality 3 was very high $($ ITC $=27.4$ ) and at locality 4 (immediately downstream a heavily polluted water discharge point) it dropped to ITC $=17.7$, then after a distance of $34.9 \mathrm{~km}$, at locality 5 , it increased again to ITC $=26.5$; at locality 6 it dropped to ITC $=22.3$ and $8.1 \mathrm{~km}$ further downstream, at locality 7, it increased to ITC $=26.9$ (Savić, 2012). On the other hand, the situation was different between localities 8 and 9 where, instead of the expected increase of ITC, its value decreased from ITC $=24.1$ to ITC $=21.9$. The distance between these two localities is only $4.8 \mathrm{~km}$, which suggest that the minimal distance of the river self-purification processes to became effective is at least $8 \mathrm{~km}$. However, these assumptions have to be analysed in detail in the future studies, comprising the entire macrozoobenthos assemblage in the Nišava River. First two axes of CA explain $61.5 \%$ of total data variability (Figure 4). Localities 1 and 3 , in the upper course of the Nišava river, are isolated from other sampling sites. These two unpolluted localities are inhabited by species Berea pullata, Ernodes articularis, and Melampophylax mucoreus (Hagen, 1861) that are absent from other localities. This suggests that these species are indicators of good water quality, which is in line with the findings of Graf et al. (2008).

The partial CCA, used to analyze the influence of four subsets of environmental variables on caddisfly assemblage, and the forward selection of 17 environmental variables, extracted only 6 variables that are significantly related to analyzed caddisfly species. The statistically important variables include three chemical variables $\left(\mathrm{BOD}_{5}, \mathrm{pH}\right.$, and concentration of phosphorus), two spatial variables (DM - distance of the sampling point from the river mouth, and PW position of the sampling point from the nearest wastewater discharge point), and one physical variable (turbidity). Since the caddisfly assembly is significantly influenced with $\mathrm{BOD}_{5}$ and concentration of phosphorus, we may assume that the structure of the assembly reflects the organic pollution and eutrophication, as suggested by Urbanič (2006).

Dissolved oxygen and $\mathrm{BOD}_{5}$ directly affect aquatic life through $\mathrm{O}_{2}$ availability and metabolism, but also indirectly through various biogeochemical processes, and it is an important water 


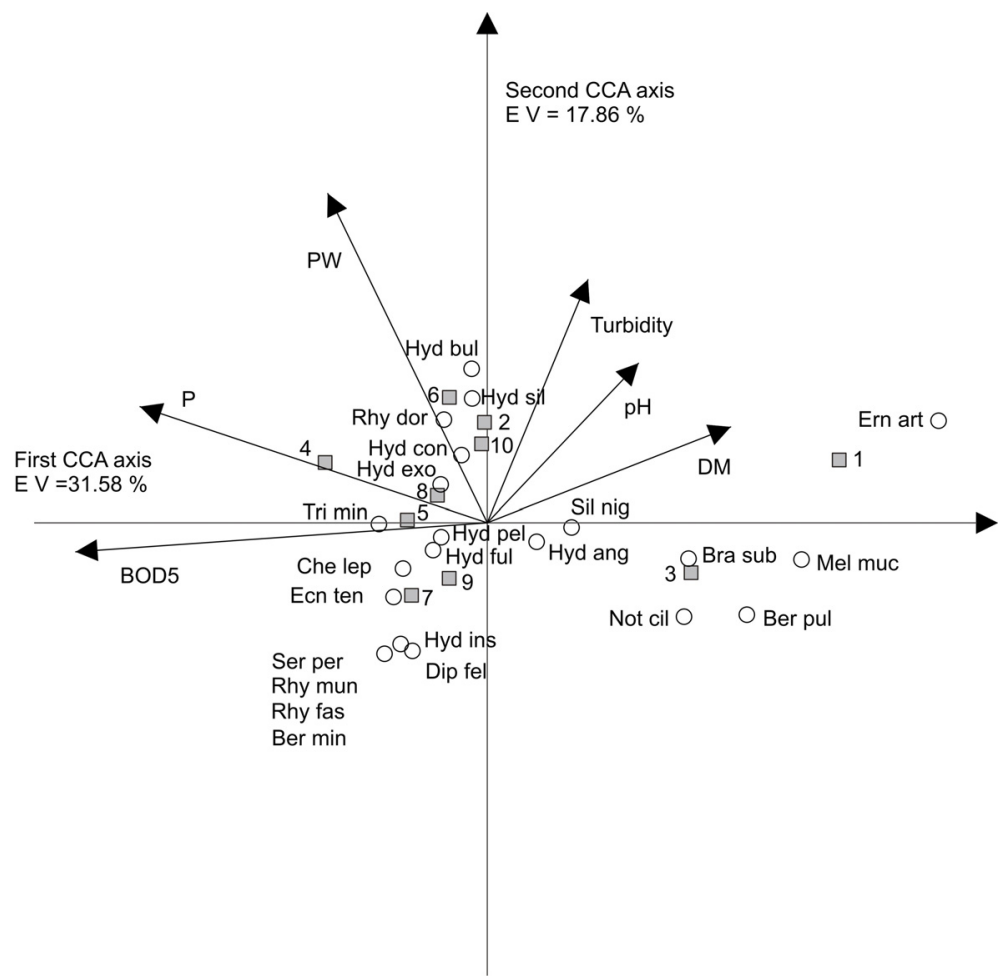

\section{Figure 5}

CCA of the caddisfly assemblage in the Nišava River; first two canonical axes account for $49.94 \%$ of total data variability. Statistically significant explanatory variables include: biochemical oxygen demand $\left(B O D_{5}\right)$; hydrogen ion concentration $(\mathrm{pH})$; concentration of total phosphorus $(\mathrm{P})$; water turbidity; distance of each sampling point from the river mouth of the Nišava River (DM); upstream/downstream position of each sampling point from the nearest wastewater discharge point (PW).

quality parameter (Hauer and Hill, 2006). As the results of our study show, the caddisfly assemblage is probably significantly determined by this parameter (Figure 5). This suggests that these insects may be useful biological indicators of aquatic ecosystem health.

The nutrients, such as TP and TN, directly influence the amount of primary production, and if they exceed certain concentrations characteristic for the particular ecosystem they may be considered pollutants, leading to a decrease in diversity (Evans-White et al., 2009). As the results of the ANOVA showed that there are significant differences between localities regarding the concentration of total $P$, and the post-hoc tests detected no significant differences between locality 10 and locality $4(p=0.783)$, this also indicates that these are the two most polluted localities, which is also confirmed by the cluster analysis (Figure 3). There are also significant differences in the concentration of total $N$ between localities. Locality 1 is significantly different from other localities regarding both total $P$ and total $N$, which is probably caused by a larger input of fallen leaves in the upper section of the river. In contrast to the concentration of total $P$, the concentration of total $N$ corresponds to the river section, which is in line with the findings of Alexander et al. (2007), Peterson et al. (2001), and Claessens et al. (2010) that stream size influences the downstream fate of nitrogen - along the stream size spectrum, headwater streams are generally considered as the most important in controlling the watershed nitrogen export (Peterson et al. 2001, Alexander et al. 2007). This suggests that the total $P$ is a better indicator of the stream health than the total $N$, which is greatly influenced by the stream section. The forward selection showed that the total $N$ was not a significant factor, contrary to the total $P$, which has a strong influence on the structure of the caddisfly assemblage, which was also confirmed by other authors (Struijs et al., 2011). However, the number of caddisfly species decreases when at least one of these two nutrients is high (such as at locality 1 ). 


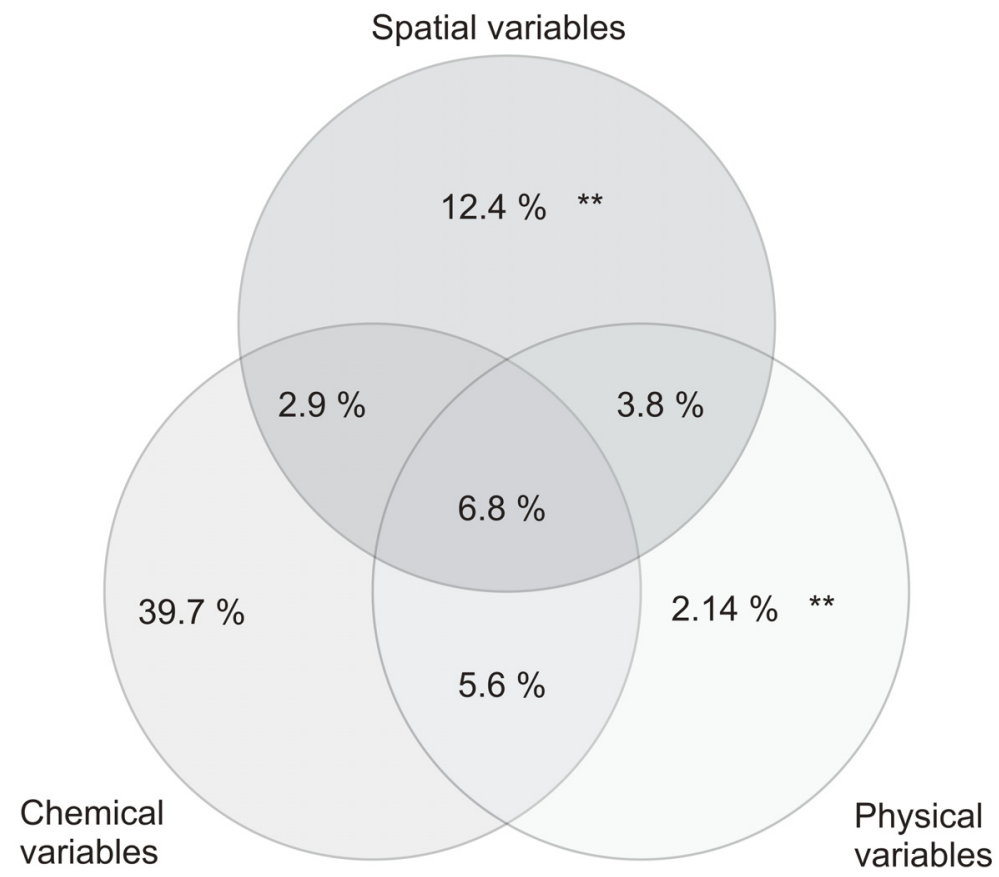

\section{Figure 6}

Venn diagram representing fractions of the total caddisfly assemblage variability explained by groups of predictor variables; fractions of spatial variables and water turbidity (a physical variable) are statistically significant.

The partial CCA was also used to detect percentages of total variability of the caddisfly assembly explained by groups of predictor variables, and the results of the variance decomposition are presented with the Venn diagram (Figure 6). Three groups of selected explanatory variables explain $73.34 \%$ of total variability. Fractions of spatial variables (DM and PW) and water turbidity were statistically significant.

Results of the CCA clearly indicate that the $\mathrm{BOD}_{5}$ increases towards the river mouth, and that this variable, along with the distance of each sampling point from the river mouth (DM) strongly affect the differentiation of caddisfly assemblage (Figure 5).

The position of each sampling from the nearest wastewater discharge point (PW) is also an important variable that indicates the significance of anthropogenic impact on the caddisfly assemblage. The vector of this variable separates the even-numbered localities, which are positioned downstream of wastewater discharge points, from odd-numbered localities. As the concentration of phosphorus also increases downstream, this suggests that the position of the locality along the course of the river as well as the anthropogenic impact are the main factors that affect the differentiation of the caddisfly assemblage in the Nišava River.

The greatest mean annual Shannon's diversity index was recorded at locality 7 , which differs from the other localities in many criteria. It was characterized by the highest level of oxygen and high percentage of stable substrate. It was observed that the substrate type is an important factor for Trichoptera species diversity, and this was confirmed in other parts of the Balkan Peninsula (Habdija et al., 2002). Another locality characterized by a high percentage of stable substrate was locality 8 , where the value of Shannon's diversity index was much lower, however the oxygen concentration was low at this locality. These results suggest that concentration of oxygen is probably a more important factor than type of substrate in influencing the species diversity. 
Localities 4 and 10 stand out as localities with the lowest species diversity. Locality 10 was characterized by the lowest average annual oxygen concentration, and locality 4 by the highest annual average TN concentration and the high average TP concentration. Locality 4 also has the lowest percentage of stable substrate.

Because of the low values of Shannon's diversity index, these two localities are also similar to locality 1 . This locality also had a low value of average annual oxygen concentration, but the decreased diversity at this locality (yet still higher than at locality 4 and locality 10) may be also attributed to the fact that at this site the Nišava is still a small river, with a low selection of microhabitats. This matches the claims that alpha diversity is generally lower in headwater streams (Clarke et al., 2008).

The value of Simpson's index is smallest at locality 7 and highest at localities 4 and 10, supporting the hypothesis that at more polluted localities the community becomes more uniform, excluding many of the less tolerant species just as in the case of the Ephemeroptera group (Savić et al., 2011).

As the clustering clearly separated locality 1 from all other localities (Figure 3 ), this suggests that there are two distinct sections along the Nišava River. The first section comprises the upper part of the river, which includes only locality 1. The species Ernodes articularis was detected exclusively at this locality, and it is well-known that insects living in the headwaters are "primitive" cool-adapted, rheobiont species (Illies, 1961; Statzner and Dolédec, 2011). The second section comprises the middle and the lower part of the river and it includes all other localities.

The highest percentage of shredders was found at locality $1(50 \%)$ and it decreased downstream. From the locality 6 and further, this group is completely lacking, which is in line with the RCC. The group is also absent from localities 2 and 4, and since these are even numbered localities, which are positioned downstream of the settlements, their water quality is poor (Savić, 2012) in comparison to odd numbered localities, which are positioned upstream from the settlements. This also correspond to the findings of Pavluk et al. (2000) that the trophic completeness is higher at sites with better water quality and that the absence of certain functional feeding groups can be related to anthropogenic activity. The percentage of collectors was lowest at locality 1 and highest at the downstream localities, which is also in line with the RCC. Nevertheless, the increase in stream order is not strictly following the pattern of the increase of collectors. This can be probably explained with the influence of the water quality, i.e. with the low trophic completeness influenced by pollution. Localities with the lowest trophic completeness (4 and 10), with only one functional feeding group present, are in the same time the localities with the worst water quality (Savić, 2012). No regular patterns in longitudinal distributions of scrapers and predators were observed.

Considering that we have analyzed abundances and not the biomass of the functional feeding groups, and that some of the localities are highly impacted, such data are less suitable for testing the RCC (Greathouse and Pringle, 2006). The testing should be done with the complete macroinvertebrate assemblage; if only caddisflies are used, it appears that the concept does not apply to this river to a large degree and that the trophic structure is substantially influenced by pollution. All four FFGs were present only at locality 3 , and three groups at localities 1 and 7 . These are the localities with the best water quality (Savić, 2012), which suggests that the level of trophic completeness, even in scope of a single assemblage (in this case caddisflies), can be used as a water quality indicator, as shown by Pavluk et al. (2000) for the entire macrozoobenthos assemblage.

The caddisfly assemblage has shown a definite and precise correlation with certain physicochemical parameters in our study. Since previous studies of macroinvertebrate communities in the rivers of the Central Balkan Peninsula have shown that Trichoptera are the dominant component of the zoobenthos (Jović et al., 2006), our results support the hypothesis that this group is suitable for use as biological indicators. 


\section{ACKNOWLEDGEMENTS}

This paper is published as part of the Project No. 173045 and Project No. 173030 of the Ministry of Education, Science and Technological Development of the Republic of Serbia. The authors give their thanks to two anonymous referees for critically reviewing and significantly improving the manuscript.

\section{REFERENCES}

Alexander R.B., Boyer E.W., Smith R.A., Schwarz G.E. and Moore R.B., 2007. The role of headwater streams in downstream water quality. J. Am. Water Resour. Assoc., 43, 41-59.

Allan J.D., 1995. Stream ecology. Chapman \& Hall, London, 388 p.

APHA, 1999. Standard methods for the examination of water and wastewater, 20th edn. Washington, DC, APHA.

Blanchet F.G., Legendre P. and Borcard D., 2008. Forward selection of explanatory variables. Ecology, 89, 2623-2632.

Blaženčić J., Ranđelović V., Butorac B., Vukojičić S., Žukovec D., Ćalić I., Pavićević D. and Lakušić D., 2005. Habitats of Serbia. Institute of Botany and Botanical Garden "Jevremovac", Faculty of Biology, University of Belgrade, 684 p. (in Serbian).

Bonada N., Zamora-Munoz C., Rieradevall M. and Prat N., 2004. Ecological Profiles of Caddisfly Larvae in Mediterranean Streams: Implication for Bioassessment Methods. Environ. Pollut., 132, 509-521.

Borcard D., Legendre P. and Drapeau P., 1992. Partialling out the spatial component of ecological variation. Ecology 73, 1045-1055.

Branković S., Simić V. and Trajković S., 2007. A hydrobiological study of the Nišava River according to the Water Framework Directive. Zbornik radova Građevinsko-arhitektonskog fakulteta, Niš, $143-148$ (in Serbian).

Buss P.F., Baptista P.F., Nessimian J.L. and Egler M., 2004. Substrate specifity, environmental degradation and disturbance structuring macroinvertebrate assemblages in neotropical streams. Hydrobiologia, 518, 179-188.

Claessens L., Tague C.L., Groffman P.M. and Melack J.M., 2010. Longitudinal assessment of the effect of concentration on stream N uptake rates in an urbanizing watershed. Biogeochemistry, 98, 63-74.

Clarke, A., Mac Nally R., Bond N. and Lake P.S., 2008. Macroinvertebrate diversity in inland water streams: a review. Fresh. Biol., 53, 1707-1721.

Cox B.A., 2003. A review of currently available in-stream water-quality models and their applicability for simulating dissolved oxygen in lowland rivers. Sci. Total Environ. 314-316, 335-377.

Culp J.M., 1987. The effects of streambank clearcutting on the benthic invertebrates of Carnation Creek, British Columbia. In: Chamberlin T.W. (ed.), Proceeding of the Workshop: Applying 15 Year of Carnation Creek Results, Nanaimo, British Columbia, Carnation Creek Steering Committee, c/o Pac. Biol. Sta. Nanaimo, B.C., 75-80.

Cummins K.W., 1973. Trophic relations of aquatic insects. Annu. Rev. Entomol., 18, 183-206.

Czachorowski S., and Serafin E., 2004. The distribution and ecology of Hydropsyche bulgaromanorum and Hydropsyche contubernalis (Trichoptera: Hydropsychidae) in Poland and Belarus. Lauterbornia, 50, 85-98.

Dohet A., 2002. Are caddisflies an ideal group for the biological assessment of water quality in streams? Nova Supplementa Entomologica, 15, 507-520.

Dolédec S. and Statzner B., 2010. Responses of freshwater biota to human disturbance: contributions of J-NABS to developments in ecological integrity assessments. J. N. Am. Benthol. Soc., 29, 286-311.

Edington J.M. and Hildrew A.G., 1995. A revised key to the caseless caddis larvae of the British Isles, with notes on their ecology. Freshwater Biological Association, Scientific Publication, Vol. 53, $134 \mathrm{p}$.

ESRI, 2009. ArcGIS Desktop and Spatial Analyst. Environmental Systems Research Institute, Inc., Redlands, CA. 
Evans-White M.A., Dodds W.K., Huggins D.G. and Baker, D.S., 2009. Thresholds in macroinvertebrate biodiversity and stoichiometry across water-quality gradients in Central Plains (USA) streams. J. North Amer. Benthol. Soc., 28, 855-868.

Fengqing L., Qinghua C., Wanxiang J. and Xiaodong Q., 2012. Macroinvertebrate relationships with water temperature and water flow in subtropical monsoon streams of Central China: implications for climate change. Fund. Appl. Limnol., 180, 221-231.

Galbraith H.S., Vaughn C.C. and Meier K.C., 2008. Environmental variables interact across spatial scales to structure trichopteran assemblages in Ovachita Mountain Rivers. Hydrobiologia, 596, 401-411.

Gordon N.D., McMahon T.A. and Finlayson B.L., 1992. Stream hydrology: An introduction for ecologists. Wiley \& Sons, Chichester, $526 \mathrm{p}$.

Graf W. and Schmidt-Kloiber, A., 2011. Additions to and update of the Trichoptera Indicator Database. www.freshwaterecology.info, version 5.0.

Graf W., Grasser U. and Waringer J., 1995. Trichoptera. In: Moog, O. (ed.). Fauna Aquatica Austriaca, Lieferung 1995. Wasserwirtschaftskataster, Bundesministerium für Land- und Forstwirtschaft, Wien.

Graf W., Murphy, J., Dahl, J., Zamora-Muñoz, C., López-Rodríguez M.J. and Schmidt-Kloiber., A., 2006. Trichoptera Indicator Database. Euro-limpacs project, Workpackage 7 - Indicators of ecosystem health, Task 4, www.freshwaterecology.info, version 5.0.

Graf W., Murphy J., Dahl J., Zamora-Muñoz C. and López-Rodríguez M.J. 2008. Distribution and ecological preferences of European freshwater organisms. Trichoptera. Pensoft Publishers, SofiaMoscow, Vol. 1, $388 \mathrm{p}$.

Greathouse E.A. and Pringle C.M., 2006. Does the river continuum concept apply on a tropical island? Longitudinal variation in a Puerto Rican stream. Can. J. Fish. Aquat. Sci., 63, 134-152.

Gurtz M.E. and Wallace J .B., 1984. Substrate-mediated response of stream invertebrates to disturbance. Ecology, 65, 1556-1569.

Habdija I., Radanović I., Primc-Habdija B. and Špoljar M., 2002. Vegetation cover and substrate type as factors influencing the spatial distribution of trichopterans along a karstic River. Int. Rev. Hydrobiol., 87, 423-437.

Hauer F.R. and Hill W.R., 2006. Temperature, Light and Oxygen. In: Hauer, F.R. and Lamberti, G.A. (eds.), Methods in stream ecology, Academic Press Elsevier, New York, 103-119.

Helms B.S., Schoonover J.E. and Feminella J.W., 2009. Seasonal variability of land use impacts on macroinvertebrate assemblages in streams of western Georgia, USA. J. North Amer. Benthol. Soc., 28, 991-1006.

Hill M.O., 1979. DECORANA - A FORTRAN program for detrended correspondence analysis an reciprocal averaging. Section of Ecology and Systematics, Cornell University, Ithaca, New York, 52 p.

Hughes S.J., 2006. Temporal and spatial distribution patterns of larvae Trichoptera in Madeiran Streams. Hydrobiologia, 553, 27-41.

Huryn A.D. and Wallace J.B., 1988. Community structure of Trichoptera in a mountain stream: spatial patterns of production and functional organization. Fresh. Biol., 20, 141-155.

Hynes H.B.N., 1979. The ecology of running waters. Liverpool university Press, Liverpool, 555 p.

Illies J., 1961. Versuch einer allgemeinen biozönotischen Gliederung der Fließgewäser. Int. Rev. Hydrobiol., 46, 205-213.

Jakovčev D., 1985. A saprobiological analysis of the Južna Morava River and its tributaries, the Nišava and the Moravica. Godišnjak Jugoslovenskog društva za zaštitu voda, 61-64 (in Serbian).

Jović, A., Paunović, M., Stojanović, B., Milošević, S. and Nikolić, V., 2006. Aquatic invertebrates of the Ribnica and Lepenica Rivers: composition of the community and water quality. Arch. Biol. Sci., $58,115-119$.

Karadžić, B. and Marinković, S., 2009. Quantitative Ecology. Institute for Biological Research "Siniša Stanković", Belgrade, 489 p. (in Serbian).

Karadžić B., Šašo-Jovanović V., Jovanović Z. and Popović R., 1998. 'FLORA' a database and software for floristic and vegetation analyses. In: Tsekos I. and Moustakas M. (eds.), Progress in Botanical Research; Proceedings of the 1st Balkan Botanical Congress, Kluwer Academic Publishers, Dodrecht, 69-72.

Krebs, C. J., 2001. Ecology: The experimental analysis of distribution, abundance. Benjamin/Cummings, San Francisco, 695 p. 
Lechthaler W. and Stockinger W., 2005. Trichoptera - Key to Larvae from Central Europe. ISBN: 3-9501839-1-4. http://www.eutaxa.com/Trichoptera\%2005\%2001.htm.

Legendre P. and Gallagher E.D. 2001. Ecologically meaningful transformations for ordination of species data. Oecologia, 129, 271-280.

Legendre P., Oksanen J. and ter Braak C.J.F., 2011. Testing the significance of canonical axes in redundancy analysis. Methods in Ecology and Evolution, 2, 269-277.

Lowe R.L. and Laliberte G.D., 2007. Benthic stream algae, distribution and structure. In: Hauer F.R. and Lamberti, G.A. (eds.). Methods in stream ecology, Academic Press Elsevier, 327-357.

Mackay R.J., 1984. Life history patterns of Hydropsyche bronata and Hydropsyche morosa (Trichoptera: Hydropsychidae) in Summer-Warm Rivers of Southern Ontario. Can. J. Zool., 62, 271-275.

Mackay R.J. and Wiggins G.B., 1979. Ecological diversity in Trichoptera. Annu. Rev. Entomol., 24, 185-208.

McCune B., 1997. Influence of noisy environmental data on canonical correspondence analysis. Ecology, 78, 2617-2623.

McCune B. and Mefford M.J., 1999. PC-ORD. Multivariate Analysis of Ecological Data, Version 4. MjM Software Design, Gleneden Beach, Oregon, USA, 237 p.

McTammany M.E., 2004. Recovery of Southern Appalachian streams from historical agriculture. Ph.D. Thesis, Virginia Polytechnic Institute and State University, Blacksburg, 145 p.

Ormerod S.J. and Edwards R.W., 1987. The ordination and classification of macroinvertebrate assemblages in the catchment of the river Wye in relation to environmental factors. Fresh. Biol., 17, 533-546.

Paul M.J., Meyer J.L. and Couch C.A., 2006. Leaf breakdown in streams differing in catchment land use. Fresh. Biol., 51, 1684-1695.

Pavluk T.I., Vaate A. bij de, Leslie H.A., 2000. Development of an Index of Trophic Completeness for benthic macroinvertebrate communities in flowing waters. Hydrobiologia, 427, 135-141.

Peterson B.J., Wollheim W.M., Mulholland P.J., Webster J.R., Meyer J.L., Tank J.L., Martí E., Bowden W.B., Valett H.M., Hershey A.E., McDowell W.H., Dodds W.K., Hamilton S.K., Gregory S. and Morrall D.D., 2001. Control of nitrogen export from watersheds by headwater streams. Science, 292, 86-90.

Reid H.E., Brierley G.J. and Boothroyd I.K.G., 2010. Influence of bed heterogeneity and habitat type on macroinvertebrate uptake in peri-urban streams. Int. J. Sediment Res., 25, 203-220.

Resh V.H. and Rosenberg D.M., 1984. The ecology of aquatic insects. Praeger Publishers, New York, $625 \mathrm{p}$.

Savić A. 2012. Ecological analysis of macrozoobenthos communities in the Nišava River. Ph.D. Thesis, Faculty of Biology, University of Belgrade, Serbia, $174 \mathrm{p}$.

Savić A., Ranđelović V. and Krpo-Ćetković J., 2010. Seasonal variability in community structure, habitat selection of mayflies (Ephemeroptera) in the Nišava River (Serbia). Biotechnol. Biotec. Eq., 24, 639-645.

Savić A., Ranđelović V., Branković S. and Krpo-Ćetković J., 2011. Mayfly (Insecta: Ephemeroptera) community structure as an indicator of the ecological status of the Nišava river (Central Balkan Peninsula). Aquat. Ecosyst. Health Manage., 14, 276-284.

Schmera D., 2004. Spatial distribution and coexistence patterns of caddisfly larvae (Trichoptera) in a Hungarian stream. Int. Rev. Hydrobiol., 89, 51-57.

Skuja A. and Spungis V. 2010. Influence of environmental factors on the distribution of caddisfly (Trichoptera) communities in medium-sized lowland stream in Latvia. Estonian J. Ecol., 59, 197-215.

Soballe D.M. and Kimmel B.L., 1987. A large-scale comparison of factors influencing phytoplankton abundance in rivers, lakes and impoundments. Ecology, 68, 1943-1954.

Sokal R.R. and Rohlf F.J., 1995. Biometry. 3rd edition. W. H. Freeman and Co., New York, 887 p.

Sponseller R.A. and Benfield E.F., 2001. Influences of land use on leaf breakdown in southern Appalachian headwater streams: a multiple-scale analysis. J. North Amer. Benthol. Soc., 20, 44-59.

Statzner B. and Dolédec S., 2011. Phylogenetic, spatial and species-trait patterns across environmental gradients: the case of Hydrops yche (Trichoptera) along the Loire River. Int. Rev. Hydrobiol., 96, 121-140. 
Strahler A.N., 1952. Hypsometric (area-altitude) analysis of erosional topology. Geol. Soc. Am. Bull., 63, $1117-1142$.

Struijs J., Dezwart P., Posthuma L., Leuven R.S. and Huijbreqts M.A., 2011. Field sensitivity distribution of macroinvertebrates for phosphorus in inland waters. Integrated Environmental Assessment and Management, 7, 280-286.

Stuijfzand S.C., Engels S., van Ammelrooy E. and Jonker M., 1999. Caddisflies (Trichoptera: Hydropsychidae) used for evaluating water quality of large European rivers. Arch. Environ. Contam. Toxicol., 36, 186-192.

Tank J.L., Rosi-Marshall E.J., Griffiths N.A., Entrekin S.A. and Stephen M.L., 2010. A review of allochthonous organic matter dynamics and metabolism in streams. J. N. Am. Benthol. Soc., 29, 118-146.

Ter Braak C.J.F., 1986. Canonical Correspondence Analysis: a new eigenvector technique for multivariate direct gradient analysis. Ecology, 67, 1167-1179.

Ter Braak C.J.F. and Prentice I.C., 1988. A theory of gradient analysis. Adv. Ecol. Res., 18, 271-317.

Ter Braak C.J.F. and Wiertz J., 1994. On the statistical analysis of vegetation change: A wetland affected by water extraction and soil acidification. J. Veg. Sci., 5, 361-372.

Townsend C.R., Arbuckle C.J., Crowl T.A. and Scarsbrook M.R., 1997. The relationship between land use and physicochemistry, food resources and macroinvertebrate communities in tributaries of the Taieri River, New Zealand: a hierarchically scaled approach. Fresh. Biol., 37, 177-191.

Urbanič G., 2006. Distribution and structure of Trichoptera assemblages in the ecoregion "Hungarian lowland" in Slovenia. In: Proceedings 36th International Conference of IAD, Austrian Committee Danube Research/IAD, Vienna, 285-289.

Urbanič G., Toman M.J. and Krušnik C., 2005. Microhabitat type selection of caddisfly larvae (Insecta: Trichoptera) in a shallow lowland stream. Hydrobiologia, 541, 1-12.

Vannote R.L., Minshall G.W., Cummins K.W., Sedell J.R. and Cushing C.E., 1980. The river continuum concept. Can. J. Fish. Aquat. Sci., 37, 130-137.

Verdonschot P.F.M., 1999. Micro-distribution of oligochaetes in a soft-bottomed lowland stream (Elsbeek; The Netherlands). Hydrobiologia, 406, 149-163.

Wallace I.D., Wallace B. and Philipson G.N., 1990. A key to the case-bearing caddis larvae of Britain and Ireland. Freshwater Biological Association, Scientific Publication, Vol. 51, 237 p.

Waringer J. and Graf W., 1997. Atlas der österreichischen Köcherfliegenlarven. Facultas Universitätsverlag, Wien, $286 \mathrm{p}$.

Waringer J. and Graf W., 2011. Atlas of Central European Trichoptera Larvae - Atlas der mitteleuropäischen Köcherfliegenlarven. Erik Mauch Verlag, Dinkelscherben, 468 p.

Wentworth C.K., 1922. A scale of grade and class terms for clastic sediments. J. Geol., 30, 377-392.

Wiggins G.B. and Mackay R.J., 1978. Some relationships between systematics and trophic ecology in Near ctic aquatic insects, with Special Reference to Trich optera, Ecology, 59, 1211-1220.

Živić I., Marković Z. and llić J., 2005. Composition, structure, and seasonal dynamics of macrozoobenthos in the Temska and Visoèica rivers (Serbia). Arch. Biol. Sci., 57, 107-118. 